Volume 5, Issue 2, 73 - 83.

ISSN: 2165-8714

http://www.eu-jer.com/

\title{
Developing the Scale of Teacher Self-Efficacy in Teaching Process
}

\author{
Fahrettin Korkmaz * \\ Ministry of Education, Turkey
}

Serkan Unsal

Kahramanmaras Sutcu Imam University, Turkey

\begin{abstract}
The purpose of this study is to develop a reliable and valid measurement tool which will reveal teachers' self-competences in education process. Participants of the study are 300 teachers working at state primary schools in the province of Gaziantep, Results of the exploratory factor analysis administered to the scale in order to determine its construct validity, indicated that it has four sub-dimensions. In accordance with the results of confirmatory factor analysis RMSEA was measured .050 level fit index. The determined levels for GFI is found to be 0.88 , whereas for AGFI, 0.85 for NFI, 0.94 for CFI 0.98 and 0.94 for RFI. Also, non normed fit index, (NNFI) has been observed as 0.97 . Four dimensions of the scale which was composed of 23 items account for approximately $54 \%$ of the total variance. Cronbach's alpha coefficient of internal consistency was counted .86 for the first dimension; .82 for the second dimension, .67 for the third dimension, .70 for the fourth dimension, and .92 for the entire scale. The scale, developed in order to measure teachers' self-efficacy in the teaching process, proved to be valid and reliable based on the results of the related analyses.
\end{abstract}

Keywords: Self efficacy, efficacy, teachers' self-efficacy, teaching process

To cite this article: Korkmaz, F., \& Unsal, S. (2016). Developing the Scale of Teacher Self-Efficacy in Teaching Process. European Journal of Educational Research, 5(2), 73-83. doi: 10.12973/eu-jer.5.2.73

\section{Introduction}

Self-efficacy refers to the self-perception of teachers resulting from observations throughout the educational period or their opinions about their own competence. The perceptions or opinions about themselves are thought to be closely related to the performances of teachers. With this respect, if the competence perception about succeeding in any task is positive than there is high chance of being successful; but if the competence perception is low, than there is a high chance of having a failure (Tepe \& Demir, 2012).

There are various definitions in the literature about self-efficacy. According to Zulkosky (2009), selfefficacy refers to beliefs of people concerning how they think, how they feel; or the things that triggers or motivates them. Self-efficacy is the belief that is related to the target that one wants to achieve. According to Stajkovic and Luthans (1979), self-efficacy refers to; self-beliefs about a given task on whether the individual himself can complete it or not. According to Bandura (1985), self-efficacy refers to the beliefs of an individual about himself on whether he can carry out the given task or not. Senemoglu (2001) defines selfefficacy as the ability to generate solutions against various problems and the perception about one's own potential. The term self-efficacy was initially used by social-cognitive theorists and especially by Bandura (Karahan, 2008).
According to Bandura $(1982,1985)$, self-efficacy refers to self-beliefs that are required to arrange one's abilities and carry out the plans. Beliefs about competence affect how a person thinks, acts and feels. According to Bandura (1985), who examined the source of self-efficacy, there are four factors that affect self-efficacy. The first and most crucial one is experience of mastery. The individual gathers various information about whether or not he will be successful. While achievements create beliefs about promoting self-efficacy; failure decreases it. The second factor that affects self-efficacy is the vicarious experience one obtains from social settings. By observing the achievements of others, the individual can generate a belief that he can achieve the same or similar task. The third factor is social persuasion. The suggestions that people receive from their surroundings about succeeding in a task can affect the self-belief about achieving it. The fourth and last factor that affects selfefficacy is physiological and emotional factors. Being emotionally and physically ready for displaying a behavior will help the individual in attempting for the task and developing a positive self-efficacy.

According to Gist and Mitchel (1992), self-efficacy of an individual is closely related to the individual's level of talent, motivation, self-perception and personality. When people with low self-efficacy encounter a difficult task, they consider this as a threat to

\footnotetext{
* Corresponding author:

Fahrettin Korkmaz,Ministry of Education, Gaziantep, Turkey

E-Mail:korkmaz2725@gmail.com
} 
themselves; and they focus on their inefficacy rather than focusing their attention to the task and successfully completing it (Yaman, Cansungu, Koray and Altincekic, 2004). Thus, it has been considered crucial to improve self-efficacy levels of people. According to Zulkovsky (2009), one or more of the following conditions should be acquired in order for a person to generate self-efficacy:

1- When an individual successfully completes a given task;

2- He can observe how someone else successfully completes a task,

3- His self-efficacy will be positively triggered when he gets a positive feedback about the completion of the task.

According to Stajkovic and Luthans (1979), selfefficacy has three dimensions. These are the significance, power and prevalence of a given task. First of these is the importance of self-efficacy. It refers to the self-belief about achieving in a task by considering its difficulty. The second is the power of self-efficacy. It refers to the self-perception about easily achieving or having difficulty in a given task. It is the self-perception despite the importance of the given task. The third one is the generality of self-efficacy; while various experiences such as computer programming require self-efficacy; other experiences like shopping can affect self-efficacy. It is clear that current literature supports the claim that self-efficacy is an important influence on human achievement in a wide variety of settings, including education, health, sports, and work (Bandura, 1997). In this context self-efficacy is a crucial element for teaching profession.

When the literature on teacher self-efficacy is considered, there are various studies on scales. Ozdemir (2008) developed a scale consisting of 40 items and 3 dimensions for examining self-efficacy beliefs of preservice teachers concerning the teaching process. Factors of the scale were named as "planning", "practice", and "evaluation". The preschool teachers' self-efficacy belief scale developed by Tepe and Demir (2012) consists of six dimensions and 37 items. These factors were defined as learning-teaching process, communication skills, family participation, planning, arranging the learning environments. The scale developed from the adaptation study Capa, Cakiroglu and Sarikaya (2005) carried out on teacher self-efficacy has 3 factors, namely as effective student participation, teaching strategies and classroom management. The teacher self-efficacy scale developed by Kan (2007) has three factors namely as planning and evaluating teaching, recognizing the student and guidance and consists of 21 items. The study, conducted by Gibson and Dembo (1984), through a scale consisting of 30 items to examine the relationship between teacher selfefficacy and observable teacher behaviors; the study carried out by Ustuner, Demirtas, Comert and
Ozer(2009) to examine secondary school teachers' selfefficacy perceptions based on variables such as gender, professional seniority and school type through Tschannen-Moran and Hoy's (2001) "Teacher SelfEfficacy Scale" can be listed as examples.

Guskey (1988) has conducted studies indicating that teachers with high self-efficacy are more apt to using new and different methods in their lessons. According to Henson, Kogan and Tammi (2000), there is a positive relationship between teacher self-efficacy and teaching effectiveness and student achievement. However, Goddard, Hoy and Woolfolk-Hoy (2000) suggest that high teacher self-efficacy does not indicate teaching effectiveness and student achievement. When the relative studies are considered, it is evident that these studies are teacher self-efficacy oriented; and there are no studies aiming at evaluating teacher self-efficacy during the teaching process. With this respect, the effects of teacher self-efficacy, which refers to educational factors (teaching process) that constitute the key element of the education system, on teaching factors is crucial. Developing a scale oriented at the teaching process of teachers is crucial in determining the relationship between teacher self-efficacy levels and the quality of the teaching process.

\section{Literature review}

There are many factors that affect teacher self-efficacy throughout the teaching process. These factors can result from the individuals themselves, the teaching environment, colleagues or the administrators.

The perception and belief of self-efficacy can closely affect the activities of teachers within the classroom. Smith (1996) states that teacher self-efficacy affects the activities carried out in the classroom. According to Midgley, Feldlaufer and Eccles (1989), who examined teacher and student self-efficacy through mathematics education, there is a relationship between self-efficacy beliefs of teachers and student performances. With this respect, while the self-efficacy perceptions of students, whose teachers have low self-efficacy perceptions, are negatively affected in time; self-efficacy perceptions of students, whose teachers have high self-efficacy perceptions, were observed to be affected positively in time.

Self-efficacy perceptions of teachers throughout the instructional period are crucial for their professional performances. We can identify whether or not a teacher displays effective teacher behaviors during the educational period through how they define and perceive their own professional performances. Individuals with high self-efficacy levels put great effort for achieving a task, don't give up when they encounter negative situations and follow their path towards the solution with patience (Askar and Umay, 2001). 
Skaalvik and Skaalvik (2007) examined the relationship between teacher self-efficacy and perceived collective competency, the stress factor and burnout. Their study emphasizes that there is a strong relationship between teacher self-efficacy and burnout and collective teacher self-efficacy. Furthermore, the study conducted by Skaalvik and Skaalvik (2010) suggests that there is a strong relationship between teacher self-efficacy and burnout. According to the study conducted by Caprara, Barbaranelli and Steca Malone (2006), who examined the relationship between teacher self-efficacy and student achievement and teacher job satisfaction, teacher efficacy affects student achievement and teacher job satisfaction. The study that Schwarzer and Hallum (2008) conducted was focused on teacher efficacy, job stress and professional burnout. The study suggested a crucial relationship between professional burnout, job stress and efficacy perceptions of teachers.

There is a significant relationship between self-efficacy beliefs of teachers and student achievement, learning outputs of students, student motivation, attitudes towards the course and academic performance (Comert, Demirtas, Ozer and Ustuner, 2009). On the other hand, there is a direct relationship between teachers' self-efficacy beliefs and issues such as classroom behaviors of teachers, openness towards new ideas, developing positive attitudes towards learning, having effective classroom management skills, professional commitment and having effective teaching (Comert et al., 2009; Cakiroglu, Ozkan and Tekkaya, 2002; Gercek, Koseoglu, Soran and Yilmaz, 2005).

According to Scott (1996), who emphasized the significance of self-efficacy in the teaching process, many of the educators believe that students have the control of their own self-efficacy. However, this is a miscomprehension. Students with low self-efficacy will fail in any given task if they have a weak self-efficacy belief about the task or think that they will fail to accomplish the task. Thus, the self-efficacy perceived by students is crucial for students. Although the relationship between self-efficacy and learning has not fully been identified, it can be asserted that there is a close relationship between self-efficacy and talent.

According to Prendergast, Garvis and Keogh (2011), who conducted studies on teacher self-efficacy, teacher self-efficacy is a crucial structure which shapes teacher effectiveness and motivates the teacher. While teachers with high level of self-efficacy are more flexible in teaching and have more potential to strive to help all students; teachers with low level of self-efficacy have a lower chance of striving to help all students in achieving their learning needs. According to Garvis and Pendergast (2011), who examined teacher self-efficacy during early childhood period, there is a positive relationship between high level of teacher self-efficacy and the quality of instruction given to the student.

Self-efficacy refers to a process rather than a belief that emerges suddenly in an individual. Teachers gain selfefficacy through the experiences or professional development resulting from the instructional periods. Self-efficacy is not a stable, constant concept but rather changes from person to person and even from the various areas where a person can work in. When teacher efficacy is considered from this point of view, it can be stated that a teacher who feels rather competent in one field can feel incompetent in another field.

According to Bandura (1985), who expressed that there are rapid changes in the educational system due to the developments in technology, a qualified education should aim at contributing to the life quality of an individual. Thus, one of the goals of education should be furnishing students with the sense of selfefficacy which they can use throughout their whole life. The self-efficacy regulation process has a crucial role in the mental development process. Self-efficacy belief offers 3 principles which contribute to the academic achievement of an individual. These are; beliefs oriented on various academic subjects of students and their self-learning competences; beliefs oriented on learning encouragements made by teachers to their students and teacher self-efficacy beliefs about encouraging students; the collective academic achievements of schools.

According to Oettingen (1985), teachers play a key role in the development of student self-efficacy. When evaluating their self-efficacy levels in the school setting, students are for the most part affected by the evaluations made by their teachers. Students tend to evaluate their self-efficacy levels according to the perspective of their teachers. Self-efficacy perceptions will decrease in students who fail to display academic performance expected according to their emotional state. The unquestionable authority of teachers will negatively affect the emotional state of students and damage their positive self-efficacy. Alwan and Mahasneh (2014) also underline that teacher-student relationships throughout the learning process significantly affect the perception of self-efficacy. Teacher self-efficacy beliefs are considered as an important factor that affects the attitudes of students towards the school.

Teacher self-efficacy is effective in students' generating positive or negative attitudes towards their school. Thus, there is a close relationship between teacher selfefficacy beliefs and student attitudes towards the school. Teacher self-efficacy is a crucial variable in increasing educational quality, classroom management, increasing student achievement, implementing the management and strategies and increasing motivation and achievement (Woolfolk, Rosoff, Hoy, 1990; AlAlwan and Mahasneh, 2014; Tschannen-Moran, 
Woolfolk Hoy, 2002). According to Friedman (2003), there is a reverse correlation between self-efficacy and burnout concerning the teaching profession. Thus, job burnout decreases as job competency increases.

The effectiveness of a teacher with a high level of selfefficacy will be even more evident in the teaching process (Ozata, 2007, p: 23-24). According to Kaptan and Korkmaz (2002), there is a positive correlation between the sense of self-efficacy and the effort to complete a given task. According to Bikmaz (2004), a person with high self-efficacy tends to strive to solve a problem he encounters while accomplishing a given task.

Self-efficacy beliefs of teachers concerning the teaching process is the most effective factor in increasing student achievement, motivation and desires to learn along with arranging and planning the teachinglearning settings and organizing issues such as classroom management (Ozdemir, 2008).

When the literature is considered, examples of studies carried out on determining teacher self-efficacy levels are; "Teacher Competency Scale" developed by Arslan and Sunbul (2006), the "Teacher Self-Efficacy Scale" developed by Bandura (1997) and the scale adaptation study conducted by Capa, Cakiroglu and Sarikaya (2005) to determine teacher self-efficacy. Examples of self-efficacy scales developed for various fields can be listed as; the "Biology Teachers' Self-Efficacy Beliefs concerning Biology Teaching" scale developed by Cakiroglu and Savran (2001), the "Preservice Teachers' Self-Efficacy Beliefs Concerning Chemistry Teaching" scale developed by Morgil, Secken and Yucel (2004), the "Mathematic Literacy Self-Efficacy scale" developed by Bindak and Ozgen and the "Computer Teaching SelfEfficacy Scale" developed by Akkoyunlu, Orhan and Umay (2005).

When the teacher oriented self-efficacy scales in the literature are considered, it is evident that there are no scales that aim at determining self-efficacy levels of teachers concerning the teaching process. With this respect, this study aimed at developing a scale which can be used in determining teacher self-efficacy levels in the teaching process.

\section{Methodology}

The population and sample, data collection instruments, purpose of the study, data collection and data analysis are given in this section.

\section{Purpose of the Study}

The purpose of this study was to develop a scale for determining teacher self-efficacy throughout the teaching process.

\section{Study Group}

This study was a scale development study which aimed at determining teacher self-efficacy about the teaching process. The simple random sampling method was used in selecting the study sample. In this sampling method, each unit in the population has the equal chance of being selected in the sample and the selection of a unit does not affect the selection of other units (Buyukozturk, Cakmak, Akgun, Karadeniz and Demirel, 2013). With this respect, the study was conducted with 350 teachers working in various types of schools in Gaziantep. 310 of the 350 scale forms distributed to the teachers were recollected. 10 forms were not included in the study because they were incomplete or filled in wrong. The statistical practices for developing a scale were conducted on 300 scale forms. The demographic information about the participant teachers are given on Table 1.

Table: 1 Descriptive data on the group subject to implementation

\begin{tabular}{|c|c|c|c|c|c|}
\hline $\begin{array}{l}\text { Professional } \\
\text { Status }\end{array}$ & $\mathbf{N}$ & $\%$ & Gender & $\mathbf{N}$ & $\%$ \\
\hline $\begin{array}{l}\text { Primary } \\
\text { School }\end{array}$ & 95 & 32 & $\begin{array}{c}\text { Male } \\
\text { Female }\end{array}$ & $\begin{array}{l}55 \\
40\end{array}$ & $\begin{array}{l}57 \\
33\end{array}$ \\
\hline $\begin{array}{l}\text { Secondary } \\
\text { School }\end{array}$ & 112 & 37 & $\begin{array}{c}\text { Male } \\
\text { Female }\end{array}$ & $\begin{array}{l}62 \\
50\end{array}$ & $\begin{array}{l}55 \\
45\end{array}$ \\
\hline High School & 93 & 31 & $\begin{array}{c}\text { Male } \\
\text { Female }\end{array}$ & $\begin{array}{l}55 \\
38\end{array}$ & $\begin{array}{l}59 \\
41\end{array}$ \\
\hline Total & 300 & 100 & $\begin{array}{c}\text { Male } \\
\text { Female } \\
\text { Total }\end{array}$ & $\begin{array}{l}172 \\
128 \\
300 \\
\end{array}$ & $\begin{array}{c}56 \\
46 \\
100 \\
\end{array}$ \\
\hline
\end{tabular}

It is evident that $172(59.4 \%)$ of the participants were male and 128 (46.6\%) participants were female. According to their profession, 95 (32\%) teachers work in primary, 112 (37\%) work in secondary and 93 (31\%) work in high school.

\section{Developing the Data Collection Instrument}

A literature review was initially carried out prior to the scale development process; namely, studies previously conducted with a focus on developing scales for teacher self-efficacy by Arslan and Sunbul (2006), Bandura (1997), Capa, Cakiroglu and Sarikaya (2005), Cakiroglu and Savran (2001), Morgil, Secken and Yucel (2004), Bindak and Ozgen (2008), Akkoyunlu, Orhan and Umay (2005), Ozdemir (2008) and Uysal and Kosemen (2008) were examined. Subsequently, a scale of teachers' self-efficacy for teaching process comprising of 23 original items was developed by the researchers.

An item pool consisting of 30 items was created after the literature review. The item pool was presented to 
an evaluation-assessment expert and instructors who are experts in the field of educational programs and teaching. They were asked to match the items and make additions or reductions to the items. After the revision, 4 items were excluded from the item pool consisting of 30 items and a trial form was developed with 26 items. The responses for the items were determined as (1) never, (2) rarely, (3) sometimes, (4) often and (5) always. Data of the scale were collected from teachers who were working in various grades and branches in Gaziantep during the 2015-2016 academic period.

\section{Data Analysis}

The data were transferred to the SPSS 17.0 software, and the demographic information about the participants and reliability studies were conducted through this program. Validity refers to the measurability degree of a given item to be measured. In other words, it refers to the extent of how accurately a scale measures a particular characteristic separately from other characteristics. Content related validity, criterion related validity, structure related validity and aspect related validity can be used when determining the validity of a measurement instrument. According to Buyukozturk (2006) and Karasar (2000) there are three validity criteria which are content validity, implementation validity and construct validity. In content validity, whether or not the questions refer to the thing and content to be measured is discussed by a group of experts. In this study, opinions of experts in evaluation and assessment, and two in the field of educational programs and teaching on the content validity of the scale were elicited.

Subsequently, the exploratory and confirmatory factor analyses were conducted to determine the factor structure of the scale of Teaching Process Self-Efficacy Level of Teachers. The exploratory factor analysis (EFA) was conducted using SPSS 17.0 software, and the confirmatory factor analysis was conducted through the LISREL 8.54 software. Finally,

The Cronbach Alpha and test-retest technique were used in this study to evaluate the reliability of the scale. The Cronbach Alpha reliability coefficient, which is a sub-estimator in scale development and adaptation studies, is used especially in conditions resulting from answer degrading scales (Buyukoztuk, 2008; Secer, 2013), and it indicates the consistency of a single measurement made through the measurement scale without having to conduct more than one practices (Can, 2014).

The following section offers findings obtained from Statistical operations, which were conducted on the data of the scale for teacher self-efficacy in teaching process.

\section{Findings}

Validity Studies

In this section, findings drawn from the statistical processes of confirmatory factor analysis and exploratory factor analysis which were used to test the construct validity of the scale are described and outlined.

\section{Factor Analysis Results about Construct Validity}

Construct validity refers to the extent of how accurate a measurement scale measures an abstract or theoretical structure (Tavsancil, 2002; Secer, 2013). Factor analysis refers to transferring the data into new data sets so as to help understanding the relationship between various variables that are considered to be related to each other, and to group the variables that affect an entity (Ozdamar, 2002; Altunisik, Coskun, Bayraktaroglu, Yildirim, 2012). Both exploratory (EFA) and confirmatory (CFA) factor analyses were conducted to determine the construct validity of the scale. In scale development studies, whether or not the data are convenient for factor analysis should be initially determined. Kaiser-Mayer-Olkin (KMO) coefficient and the Barlett's Test can be conducted for this purpose.

\begin{tabular}{lc}
\multicolumn{2}{c}{ Table-2 Results of Kaiser-Meyer-Olkin (KMO) Sample } \\
\multicolumn{2}{c}{ Measurement and Bartlett's Test }
\end{tabular}

It is evident on Table- 2 that according to the analysis result which was conducted for the teaching process self-efficacy levels of teachers scale, the Kaiser-MayerOlkin (KMO) test result is .914. The Kaiser-Meyer-Olkin (KMO) test is related to the size of the sample and measures sample sufficiency. The KMO value is a value between 0.5-1.0 (Altunisik, Coskun, Bayraktaroglu and Yildirim, 2012). The sample size is considered sufficient when this value is close to 1 and many researchers accept the value to be sufficient when it is 0.60 and above (Ekici, 2002). The Bartlett's Sphericity test indicates that a factor analysis can be conducted between the other variables $\left(\chi^{2}=2078.0 ; d f=253\right.$; $\mathrm{p}=.000<.05$ ) (Buyukozturk, 2006; Pallant, 2005; Seckin, 2013; Can, 2014). 
Table-3 Factor Loads of the Teaching Process Self-Efficacy Levels of Teachers Scale

\begin{tabular}{|c|c|c|c|c|}
\hline \multirow[b]{2}{*}{ Items } & \multicolumn{4}{|c|}{ Factor Values } \\
\hline & F1 & F2 & F3 & F4 \\
\hline I emphasize effective student participation in the class. & .740 & & & \\
\hline I try to ask questions directed to comprehending the subjects. & .686 & & & \\
\hline $\begin{array}{l}\text { I try to use my voice tone and body language effectively throughout the } \\
\text { learning-teaching process. }\end{array}$ & .626 & & & \\
\hline I begin the course after taking student attention to the subject. & .625 & & & \\
\hline $\begin{array}{l}\text { I help the students gain self-confidence through activities that make the } \\
\text { students feel themselves comfortable. }\end{array}$ & .599 & & & \\
\hline $\begin{array}{l}\text { I don't move to the next subject without giving feedback or making } \\
\text { corrections. }\end{array}$ & .577 & & & \\
\hline I check the readiness levels of students before beginning the subject in class. & .518 & & & \\
\hline $\begin{array}{l}\text { I help the students acquire various thinking skills (critical, creative, problem } \\
\text { solving etc.) through activities. }\end{array}$ & .493 & & & \\
\hline $\begin{array}{l}\text { I arrange the course by triggering various areas of intelligence (visual, audial, } \\
\text { psychomotor etc.) so as to serve for individual differences. }\end{array}$ & .457 & & & \\
\hline I arrange activities according to the needs and expectations of students. & & .732 & & \\
\hline I arrange activities for increasing student motivation. & & .675 & & \\
\hline I try to related student acquisitions with daily life. & & .664 & & \\
\hline $\begin{array}{l}\text { I arrange student acquisitions so that they can convey them to their actual } \\
\text { life. }\end{array}$ & & 639 & & \\
\hline I try to create a setting in which the students can express themselves freely. & & .617 & & \\
\hline $\begin{array}{l}\text { I carry out activities (experiments, brainstorming, drama etc.) to develop } \\
\text { creative thinking. }\end{array}$ & & & .741 & \\
\hline $\begin{array}{l}\text { I use various methods and techniques (fishbone, six thinking hats, speaking } \\
\text { circle etc.) in my course. }\end{array}$ & & & .612 & \\
\hline $\begin{array}{l}\text { I try to use learning-teaching strategies, methods and techniques } \\
\text { appropriately. }\end{array}$ & & & .589 & \\
\hline $\begin{array}{l}\text { I use information and communication technologies (computer, projection, } \\
\text { the internet) in my course. }\end{array}$ & & & .467 & \\
\hline $\begin{array}{l}\text { I strive for students to obtain information from different sources } \\
\text { (encyclopedia, journals, the internet etc.). }\end{array}$ & & & & .696 \\
\hline $\begin{array}{l}\text { I create a problem state and help the students acquire information with their } \\
\text { own effort. }\end{array}$ & & & & .540 \\
\hline $\begin{array}{l}\text { I help them learn how to learn by resorting to methods and techniques such } \\
\text { as drama, role play and problem solving in the class. }\end{array}$ & & & & .513 \\
\hline I think that effective use of time during the teaching process is important. & & & & .468 \\
\hline $\begin{array}{l}\text { For an effective teaching process, I begin the class with an interesting } \\
\text { introduction (joke, memory). }\end{array}$ & & & & .432 \\
\hline
\end{tabular}

In order to determine the factor structure of the Teaching Process Self-Efficacy Level of Teachers scale, the varimax rotated factor analysis and principal components analysis were conducted. The scale was observed to be gathered under four factors with eigenvalues above 1 . The first factor accounted for
$18.32 \%$, the second factor $14 \%$, the factor $11.36 \%$ and the fourth factor explained $10.44 \%$ of the total variance. The four factors accounted for $53.92 \%$ of the total variance. Table-3 displays the rotated factor loads of the scale items. 




Figure 1. The Path Diagram and CFA Results Concerning the Factor Loads of the Teaching Process Self-Efficacy Levels of Teachers Scale

It is evident on Table- 3 that, as a result of the Rotated Component Matrix, items i9, i11, i12, i13, i14, i15, i3, i4 and i5 are under the first sub-factor dimension; i2, i19, i21, i22 and i23 are under the second sub-factor dimension; i16, i17, i18 and i20 are under the third sub-factor dimension; i1, i6, i7, i8 and i10 are under the fourth sub-factor dimension. The factor weight ratio for this study was 0.40 . Based on the factor loads on the measurement, 3 items under the expected level (0.40) and have overlapped were excluded from the scale. The dimensions resulting from the factor analysis were named as responding to individual differences, planning, method-technique variety, and competency in using different activities by the researcher after resorting to the literature and expert opinions. Confirmatory Factor Analysis (CFA) was conducted to determine whether or not the factor load resulting from the EFA is confirmed. Confirmatory factor analysis is conducted to confirm the structure resulting from the exploratory factor analysis. 
Table-2 displays the fit measurements, good fit values and acceptable fit values (Şimşek, 2007; Meydan and Şeșen, 2011; Bayram, 2011).

\begin{tabular}{llll}
\hline Examined Fit Indices & Perfect Fit & Acceptable Values of the Scale & Fit Values \\
\hline GFI & $.95 \leq \mathrm{GFI} \leq 100$ & $.90 \leq \mathrm{GFI} \leq 95$ & 0.88 \\
AGFI & $.90 \leq \mathrm{AGFI} \leq 100$ & $.85 \leq \mathrm{AGFI} \leq .90$ & 0.85 \\
CFI & $.95 \leq \mathrm{CFI} \leq 100$ & $.90 \leq \mathrm{CFI} \leq .95$ & 0.98 \\
NFI & $.95 \leq \mathrm{NFI} \leq 100$ & $.90 \leq \mathrm{NFI} \leq .95$ & 0.94 \\
NNFI & $.95(\mathrm{TLI}) \leq 1.00$ & $.90 \leq \mathrm{NNFI}(\mathrm{TLI}) \leq .95=$ & 0.97 \\
RFI & $.95 \leq \mathrm{RFI} \leq 100$ & $.90 \leq \mathrm{RFI} \leq .95$ & 0.94 \\
IFI & $.95 \leq \mathrm{IFI} \leq 100$ & $.90 \leq \mathrm{CFI} \leq .95$ & 0.98 \\
RMR & $.050 \leq \mathrm{RMR} \leq 080$ & $.000 \leq \mathrm{RMR} \leq .050$ & 0.54 \\
RMSEA & $.00 \leq \mathrm{RMSEA} \leq 05$ & $.05 \leq \mathrm{RMSEA} \leq .08$ & 0.050 \\
\hline
\end{tabular}

When the fit indices of the scale on teacher self-efficacy during the teaching process are considered; it is evident that the chi square statistic of these fit indices is $\mathrm{X}^{2}$. When this value is estimated with the degree of freedom (df)/ and if the ratio is below 3 , the fit is perfect; if it is below 5 then the fit is at acceptable level. The value $X^{2} / \mathrm{df}(346.76$ / $224=1.54)$, which resulted from the analysis conducted according to this calculation, is observed to have a prefect level of fit. The root mean square error of approximation (RMSEA) has a fit index value at .050 levels. The Goodness of Fit Index (GFI) is 0.85 and the Adjusted Goodness of Fit Index is .81. GFI and AGFI are values that are between $0-1$ range. When GFI and AGFI are at .95 and above, the fit is perfect and it is an acceptable fit when they are between .90-.94 (Cokluk, Sekercioglu and Buyukozturk, 2010). Thus, it can be observed that GFI (.85) and AGFI $(0.81)$ have an acceptable fit value. It is evident that the index of the standardized Root Mean Square Residual (RMR) is .054. Thus, the standardized RMR is at an acceptable level (Cokluk, Sekercioglu and Buyukozturk, 2010). When the Non-Normed Fit Index (NNFI) and When Comparative Fit Index (CFI) values are considered, it is evident that NNFI is .94 and CFI is .98 . When NNFI and CFI values are above .95, then the fit is at perfect level, when the values are above .90 then the fit is at acceptable level (Sumer, 2000). Thus, NNFI and CFI can be said to have a perfect fit value for the analysis that was conducted.

\section{Reliability}

Reliability refers to the consistency of the results obtained from various measures. A reliable measurement instrument gives the same values even after repeated measures. According to Karasar (1999), it is the consistency of an entity between independent measurements, it is following the same processes and obtaining the same results after using the same criteria.
Table-4 Internal Consistency and Test-Retest Reliability Coefficients of the Teaching Process Self-Efficacy Levels of Teachers Scale

\begin{tabular}{lccc}
\hline Dimensions & $\begin{array}{c}\text { Cronbach's } \\
\text { Alpha }\end{array}$ & $\begin{array}{c}\text { Test - } \\
\text { Retest }\end{array}$ & $\begin{array}{c}\text { Number } \\
\text { of Items }\end{array}$ \\
\hline Overall & .92 & .91 & 23 \\
1 $^{\text {st }}$ Dimension & .86 & .85 & 9 \\
$2^{\text {nd }}$ Dimension & .82 & .83 & 5 \\
3 $^{\text {rd }}$ Dimension & .74 & .69 & 4 \\
4 $^{\text {th }}$ Dimension & .72 & .68 & 5 \\
\hline
\end{tabular}

It is evident on Table- 4 that the test-retest reliability coefficient for the first dimension is .85; .83 for the second dimension; .69 for the third dimension; .68 for the fourth dimension and .91 for all dimensions. This result suggests that there are not many differences in the test scores with regards to time and that there is a consistency between scores. When the internal consistency results are considered, the first dimension is .86; the second dimension is .82; the third dimension is .74; the fourth dimension is 72 and the overall dimension score is .92. According to Kalayci et al. (2005), because this result is between $.80 \leq \alpha<.100$, the scale is highly reliable.

\section{Conclusion and discussion}

The purpose of this study was to develop a scale for revealing teacher self-efficacy throughout the teaching process. When the scale development studies are considered, this is a valid and reliable scale consisting of 23 items. The exploratory factor analysis, conducted to determine the construct validity of the scale, shows that the scale has four sub-dimensions as responding to individual differences, planning, method and technique variety and competency to using different activities.

When the fit indices of the scale's CFA are considered, the result "X2 / sd (346.76 / 224 = 1.54)" has a perfect fit (Sumer, 2000). The Goodness of fit Index (GFI) is 0.85 and Adjusted Goodness of Fit Index (AGFI) is .81. The GFI (.85) and AGFI (0.81) have an acceptable level 
of fit and the Standardized Root Mean Square Residual (S-RMR) index is at .054 level. Thus, the standardized RMR is at an acceptable level (Cokluk, Sekercioglu and Buyukozturk, 2010). It was observed that NNFI was .94 and CFI was .98. When NNFI and CFI values are above .95 , then the fit is at perfect level, when the values are above .90 then the fit is at acceptable level (Sumer, 2000). Thus, NNFI and CFI can be said to have a perfect fit value for the analysis that was conducted.

The Cronbach Alpha reliability coefficient, which is used to determine scale reliability, was .86 for the first factor, .82 for the second factor, .67 for the third factor, .70 for the fourth factor and .92 for the overall scale. When the internal consistency results are considered, the first dimension is .86; the second dimension is .82; the third dimension is .74; the fourth dimension is 72 and the overall dimension score is .92. With regards to these findings, reliability of the scores obtained from the teaching process self-efficacy levels of teachers scale is high.

According to the study, the teacher self-efficacy in the teaching process scale is a valid and reliable scale. Teaching process self-efficacy levels of teachers from various educational levels can be examined through various variables. Self-efficacy processes of teachers from same educational levels but different branches can be compared. Teaching process self-efficacy levels of teachers can be determined and the effects it has on student achievement can be evaluated.

\section{References}

Afacan, Ş. (2008). Müzik Öğretimi Özyeterlik Ölçeği. $A h i$ Evran Üniversitesi Kırşehir Eğitim Fakültesi Dergisi (KEFAD), 1-11.

Akkoyunlu, B. O. (2005). Bilgisayar Ögretmenleri İçin "Bilgisayar Ögretmenligi Öz-Yeterlik Ölçeği" Geliştirme Çalışması. Hacettepe Üniversitesi Eğitim Fakültesi Dergisi, 1-8.

Al-Alwan, A. F.,Mahasneh,A.M. (2014). Teachers' selfefficacy as determinant of students' attitudes toward school: a study at the school level. . Review of European Studies , 171-179.

Altunışık, $\quad$ R.Coşkun,R.,Bayraktaroğlu,S.,Yıldırım,E. (2012). Sosyal Bilimlerde Araştırma Yöntemleri Spss Uygulamaları. Sakarya: Sakarya Yayıncılık.

Așkar, P.,\&Umay,A. (2001). İlköğretim Matematik Öğretmenliği Öğrencilerinin Bilgisayarla İlgili Özyeterlik Algısı. Hacettepe Üniversitesi, Eğitim Fakültesi Dergisi, 1-8.

Atıcı, M. (2000). İlkokul öğretmenlerinin sınıf yönetiminde yetkinlik beklentisi rolünün İngiltere ve Türkiye'de seçilen bir araştırma grubu üzerinde incelenmesi. Leicester: Leicester Üniversitesi.
Ay, B. (2007). Öğretmenlerin Öz-Yeterlikleri ve Örgütsel Vatandaşlık Davranışı. Afyon: Afyon Kocatepe Üniversitesi .

Bandura, A. (1982). Self-efficacy mechanism in human agency. American psychologist, 118-122.

Bandura, A. (1985). Self-efficacy in Changing Societies. Cambridge: Cambridge University Press.

Bandura, A. (1997). Self Efficacy: The Exercise of Control. New York: Freeman and Company.

Bandura, A. (2006). Guide For Constructing SelfEfficacy Scales. F. Pajares. (Ed.). içinde, Self-Efficacy Beliefs of Adolescents (s. 307-337). Greenwich: Information Age Publishing.

Bayram, N. (2011). Yapısal Eşitlik Modellemesine Giriş Amos Uygulamaları. Yayınları, Bursa: Ezgi Kitapevi.

Bıkmaz, F. H. (2004). Özyeterlik İnançları. ( Ed). Prof. Dr. Yıldız Kuzgun içinde, Eğitimde Bireysel Farklılıklar. (s. 90-110). Ankara: Nobel Yayınları.

Bindak, R.,Özgen,K. (2008). Matematik Okuryazarlığ Öz-Yeterlik Ölçeğinin Geliştirilmesi . Kastamonu Egitim Dergisi, 517-528.

Büyüköztürk, S., Cakmak, E.C., Akgün O.E., Karadeniz S., Demirel. F. (2013). Bilimsel Araştırma Yöntemleri. Ankara: Pegem Akademi.

Büyüköztürk, Ş. (2008). Bilimsel Araştırma Yöntemleri. Ankara: Pegem Akademi Yayınları.

Caprara, G. V.,Barbaranelli,C.,Steca,P.,\&Malone,P.S. (2006). Teachers' Self-Efficacy Beliefs As Determinants of Job Satisfaction And Students' Academic Achievement: A Study At The School Level. Journal of school psychology, 473-490.

Cömert, M. D. (2009). Orta Ögretim Ögretmenlerinin Öz-Yeterlik Alglları. Mehmet Akif Ersoy Üniversitesi Egitim Fakültesi Dergisi, 1-16.

Çakıroglu, J. O. (2002). Fen Bilgisi Aday Ögretmenlerin Fen Kavramlarını Anlama Düzeyleri, Fen Ogretimine Yönelik Tutum Ve Öz-Yeterlik Ínançları. Ankara: Ortadoğu Teknik Üniversitesi.

Ekici, G. (2002). (2002) Biyoloji Öğretmenlerinin Laboratuar Dersine Yönelik Tutum Ölçeği. Hacettepe Eğitim Fakültesi Dergisi, 22-36.

Friedman, I. A. (2003). Self-Efficacy and Burnout in Teaching: The Importance of InterpersonalRelations Efficacy. Social Psychology of Education, 191-215. 
Garvis, S. \& Pendergast,D. (2011) Pre-Service StudentTeacher Self-Efficacy Beliefs: An insight into the making of teachers. Australian Journal of Teacher Education, 46-56.

Garvis, S. \& Pendergast,D. (2011). An investigation of early childhood teacher self-efficacy beliefs in the teaching of arts education. International Journal of Education \& the Arts, 9.

Gerçek, C., Köseoğlu,P.,Soran,H.,\&Yilmaz,M. (2005). Öğretmen Öz-Yeterlik İnancı. Milli Egitim Dergisi, 45-56.

Gist, M.E.,\&Mitchell,T.R. (1992). Self Efficacy: A Theorical Analysis of its Determinants And Malleability. Academy Of Management Review, 183211.

Gibson,S.,\&Dembo,M.H.(1984).Self Efficacy:A Theorical Analysis of its Determinants and

Malleability.Academy of Management Reviev. 183-211.

Goddard, R. D., Hoy W.K.\&Hoy,A.W.(2004). Collective Efficacy Beliefs: Theoretical Developments, Empirical Evidence, And Future Directions. Educational Researcher, 3-13.

Guskey, T. R. (1988). Teacher Efficacy, Self-Concept, and Attitudes Toward The İmplementation of İnstructional İnnovation. Teaching and Teacher Education, 63-69.

Gülev, D. (2008). Biyoloji Öğretmen Adaylarının Biyoloji Konularındaki. Kavram Yanılgıları, Biyoloji Öğretimine Yönelik Özyeterlik Inançları Ve Tutumları. Ankara: Gazi Üniversitesi.

Kan, A. (2007). Öğretmen Adaylarının Eğitme-Öğretme Özyetkinliğine Yönelik Ölçek Geliştirme ve EğitmeÖğretme Özyetkinlikleri Açısından Değerlendirilmesi (Mersin Üniversitesi Örneği). Mersin Üniversitesi Eğitim Fakültesi Dergisi, 35-50.

Karagöz, Y. K. (2008). İletişim becerileri Değerlendirme Ölçeğinin Faktör Analizi Metodu ile Geliştirilmesi. Dumlupınar Üniversitesi Sosyal Bilimler Dergisi, 21.

Karasar, N. (1999). Bilimsel Araştırma Yöntemi . Ankara: Nobel Yayınları.

Kurbanoğlu, S. (2004). Öz-Yeterlik inancı ve Bilgi Profesyonelleri için Önemi. Bilgi Dünyası Dergisi, 137-152.

Meydan, C. H. (2011). Yapısal Eşitlik Modellemesi Amos Uygulamaları. Ankara: Detay Yayıncılık.

Midgley, C. F. (1989). Change in Teacher Efficacy and Student Self- and Task-Related Beliefs in
Mathematics During the Transition to Junior High School. Journal of Educational Psychology, 247-258.

Oettingen, G. (1985). Cross-Cultural Perspectives On Self-Efficacy. (Ed).A.Bandura içinde, Self-Efficacy In Changing Societies, (s. 149-176. ). Newyork: Cambridge University.

Özata, H. (2007). Öğretmenlerin Öz-Yeterlik Algılarının Ve Örgütsel Yenileşmeye İlişkin Görüşlerinin Araştırılması. . Kocaeli: Kocaeli Üniversitesi Sosyal Bilimler Enstitüsü.

Özdamar, K. (2002). Paket Programlar İle Ístatistiksel Veri Analizi. Eskişehir: Kaan Kitabevi.

Özdemir, S. M. (2008). Sınıf Öğretmeni Adaylarının Öğretim Sürecine İlişkin ÖzYeterlik İnançlarının Çeşitli Değişkenler Açısından İncelenmesi. Kuram ve Uygulamada Eğitim Yönetimi , 277-306.

Pendergast, D. G. (2011). Pre-Service Student-Teacher Self-EfficacyBeliefs: An Insight Into The Making Of Teachers. Australian Journal of Teacher Education, 152-171.

Schwarzer, R. \&. (2008). Perceived teacher self-efficacy as a predictor of job stress and burnout: Mediation analyses. Applied Psychology, 152-171.

Scott, J. E. (1996). Self-efficacy: A key to literacy learning. . Reading Horizons, 195-213.

Senemoglu, N. (2001). Gelişim ve Öğrenme: Kuramdan Uygulamaya. Ankara: Gazi Yayınları.

Senemoğlu, N. (2005). Gelişim öğrenme ve öğretim. Ankara: Gazi Kitabevi.

Skaalvik, E. M. (2007). Dimensions of teacher selfefficacy and relations with strain factors, perceived collective teacher efficacy, and teacher burnout. Journal of educational psychology, 604-611.

Skaalvik, E. M. (2010). Teacher self-efficacy and teacher burnout: A study of relations. Teaching and teacher education, 1059-1069.

Stajkovic, A. (1979). Social Cognitive Theory and Self efficacy: Implications for Motivation Theory and Practice. . Organizational Dynamics, 62-74.

Sümer, N. (2000). Yapısal Eşitlik Modelleri: Temel Kavramlar Ve Örnek Uygulamalar. Türk Psikoloji Yazılar, 49-74.

Şimşek, Ö. F. (2009). Yapısal Eşitlik Modellemesine Giriş. Temel Ilkeler ve Lisrel Uygulamaları. Ankara: Ekinoks Yayınları. 
Tavşancll, E. (2002). Tutumların Ölçülmesi ve SPSS ile Veri analizi. Ankara: Nobel Yayınları.

Tepe, D.,\&Demir,K. (2012). Okul Öncesi Öğretmenlerinin Öz-Yeterlik İnançları Ölçeği. Abant İzzet Baysal Üniversitesi Eğitim Fakültesi Dergisi, 137-158.

Tschannen-Moran, M. \&Woolfolk Hoy,A. (2002). The influence of resources and support on teachers' efficacy beliefs. New Orleans: In annual meeting of the American Educational Research Association.

Umay, A. (2002). İlköğretim Matematik Öğretmenliği Programını Matematiğe Karşı Özyeterlik Algısına Etkisi. V. Ulusal Fen Bilimleri ve Matematik Eğitimi Sempozyumu. Ankara: Orta Doğu Teknik Üniversitesi.

Woolfolk, A. E. (1990). Teachers' sense of efficacy and their beliefs about managing students. Teaching and teacher Education, 137-148.

Yaman, S.,Cansüngü,K.,\&Altunçekic,A. (2004). Fen Bilgisi Öğretmen Adaylarının Özyeterlik İnanç Düzeylerinin İncelenmesi Üzerine Bir Araştırma. Türk Eğitim Bilimleri Dergisi, 355-364.

Zulkosky, K. (2009). Self-efficacy: a Concept Analysis. . Colorado: Blackwell Publishing. 